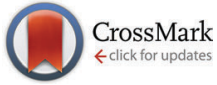

Cite this: Mol. BioSyst., 2016, 12,2024

Received 16th November 2015, Accepted 18th February 2016

DOI: $10.1039 / \mathrm{c} 5 \mathrm{mb} 00788 \mathrm{~g}$

www.rsc.org/molecularbiosystems

\section{Proteomics and the search for welfare and stress biomarkers in animal production in the one-health context $\dagger$}

\author{
A. Marco-Ramell, $\ddagger^{a}$ A. M. de Almeida, $\S^{\text {bc }}$ S. Cristobal, de $P$. Rodrigues, ${ }^{f}$ P. Roncada ${ }^{g}$ \\ and A. Bassols*a
}

\begin{abstract}
Stress and welfare are important factors in animal production in the context of growing production optimization and scrutiny by the general public. In a context in which animal and human health are intertwined aspects of the one-health concept it is of utmost importance to define the markers of stress and welfare. These are important tools for producers, retailers, regulatory agents and ultimately consumers to effectively monitor and assess the welfare state of production animals. Proteomics is the science that studies the proteins existing in a given tissue or fluid. In this review we address this topic by showing clear examples where proteomics has been used to study stress-induced changes at various levels. We adopt a multi-species (cattle, swine, small ruminants, poultry, fish and shellfish) approach under the effect of various stress inducers (handling, transport, management, nutritional, thermal and exposure to pollutants) clearly demonstrating how proteomics and systems biology are key elements to the study of stress and welfare in farm animals and powerful tools for animal welfare, health and productivity.
\end{abstract}

\section{Introduction}

In animal science, as in all life sciences, the use of proteomics and other post-genomic tools offers excellent opportunities to obtain a more detailed understanding of the complex biological systems that control the physiology and pathology of living organisms. Indeed, the use of proteomics allows the confirmation of the presence of proteins, the real effectors of genes, and it is able to provide a direct measure of the quantity of proteins present. Farm animals are raised in large-scale operations,

\footnotetext{
${ }^{a}$ Departament de Bioquímica i Biologia Molecular, Facultat de Veterinària, Universitat Autònoma de Barcelona, 08193 Cerdanyola del Vallès, Spain. E-mail: anna.bassols@uab.cat

${ }^{b}$ Instituto de Biologia Experimental e Tecnologica, Oeiras, Portugal

${ }^{c}$ CIISA/FMV - Centro Interdisciplinar de Investigação em Sanidade Animal, Faculdade de Medicina Veterinária, Universidade de Lisboa, Lisboa, Portugal

${ }^{d}$ Department of Clinical and Experimental Medicine, Cell Biology, Faculty of Medicine, Linköping University, Linköping, Sweden

${ }^{e}$ IKERBASQUE, Basque Foundation for Science, Department of Physiology, Faculty of Medicine and Dentistry, University of the Basque Country, Leioa, Spain ${ }^{f}$ CCMAR, Center of Marine Science, University of Algarve, Campus de Gambelas, 8005-139 Faro, Portugal

${ }^{g}$ Istituto Sperimentale Italiano L. Spallanzani, Milano, Italy

$\dagger$ Electronic supplementary information (ESI) available. See DOI: 10.1039/c5mb00788g ¥ Present address: Biomarkers and Nutrimetabolomics Group, Nutrition and Food Science Dept, Pharmacy School, University of Barcelona, Spain.

$\S$ Present address: Ross University School of Veterinary Medicine, Basseterre, St. Kitts and Nevis, West Indies.
}

aiming to obtain animal products for human consumption. In this context, we can consider the one health concept, the integrated approach of veterinary and human medicine focused on the prevention and control of animal and zoonotic diseases, that can include the one health proteomics concept. ${ }^{1}$ In fact, the connection between animal health, food of animal origin, and human health is more than evident for public opinion and consumers. ${ }^{2}$

In particular, animal welfare and stress are important issues because of public perception, marketing and product acceptance, and also to improve production efficiency and the quality of food products. Stress is very important in animal production and affects all animal species, including birds and fish, and even invertebrates such as shellfish. It is a complex condition that includes physical and psychological stress, as well as the deleterious effects that the environment may have on the condition of the individual (Fig. 1). ${ }^{3}$

In this article, we will revise the contribution of proteomics to the understanding of the stress caused by management conditions (housing, road transport, among others) as well as other more general conditions such as heat stress, nutritional stress and toxicological stress. Attention will be focused on candidate biomarkers that are predicted on the basis of information transfer criteria across the tissue-biofluid channels. Significant biofluidtissue relationships can be used to assess the clinical validation of biomarkers that are mandatory in the study of animal stress.

In the last 20 years, high throughput technologies led to the development of proteomics, that, particularly in the field of 


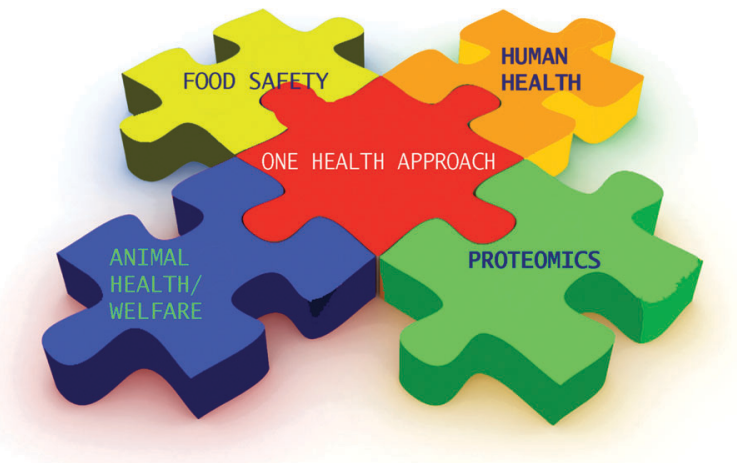

Fig. 1 One health approach links human and animal health, including animal welfare and food safety. Proteomics is a key piece that helps to complete the puzzle.

animal stress, is oriented mainly to the research on biomarkers in biological fluids and/or tissues. We can consider the top-down approach that starts from entire proteins and isoforms and then identifies specific proteins; and the bottom-up approach that digests extracts with a protease (e.g. trypsin) and then, on the peptide basis, assigns their identification and quantitation (see details in Fig. 2). ${ }^{4}$ Both approaches are valid, sometimes are complementary, and we can choose one with respect to the other on the basis of the sample type, quantity of the sample/limit of detection of putative biomarkers, the necessity to investigate post translational modification and numerous other factors. Moreover, in animal stress and also in general functional proteomics, validation is a bottleneck to enforce the biological study but it is mandatory before the development of robust and rapid tests that help to quickly diagnose the condition. Proteins produced during a particular condition could be detected using different techniques, such as immunohistochemical staining, western blot analysis, enzyme linked immunosorbent assay (ELISA) and mass spectrometry (in particular SRM-selective reaction monitoring). All these methods are powerful techniques to validate proteomic results. Moreover, secretomics, a subfield of proteomics that studies secreted proteins and secretion
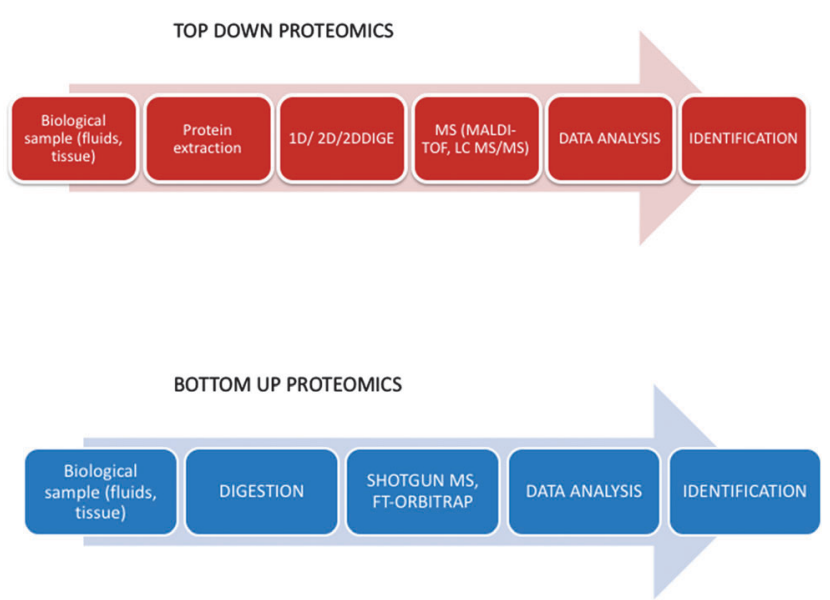

Fig. 2 The top-down and bottom-up proteomic approaches for biomarker discovery.

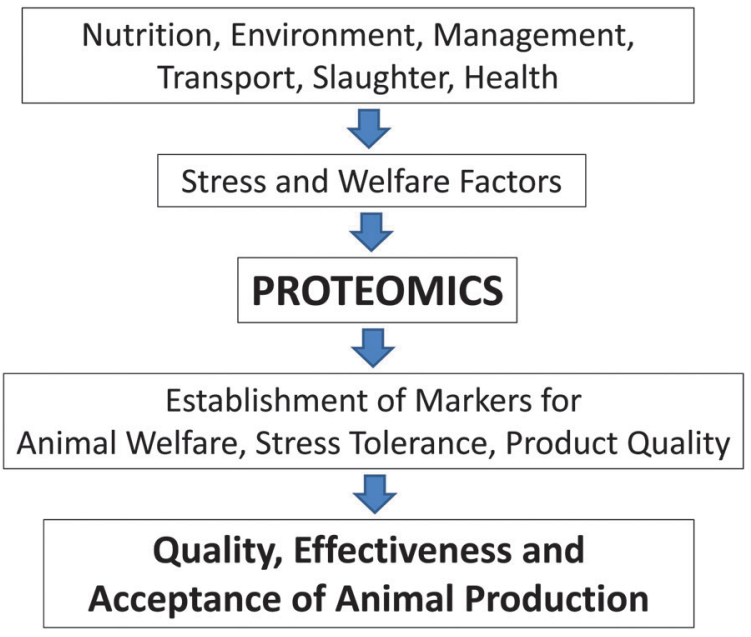

Fig. 3 The role of proteomics in the search for biomarkers for animal stress and welfare will improve the public acceptance of animal production and food of animal origin.

pathways using proteomic approaches, has recently emerged as an important tool for the discovery of biomarkers of diseases. ${ }^{5}$

Although stress and welfare have been the focus of intensive research in the field of ethology and many studies on behaviour have been performed, objective laboratory biomarkers to assess the degree of welfare in farm animals would be very useful and complementary to the behavioral tests. Several laboratory parameters have been used to assess animal stress but they are far from perfect. Cortisol, the classical hormone stress marker, has several drawbacks due to the high intra- and inter-individual variability. ${ }^{6}$ Other parameters such as acute phase proteins (APPs) have been proposed as stress indicators, but the knowledge about their role is still fragmented especially in less studied species. Proteomics is a global, nonhypothesis driven approach most adequate for the search of new biomarkers. When appropriate biomarkers will be available to assess animal welfare and stress tolerance as well as their effects on the final product, the quality and effectiveness of animal production will improve, leading to a higher acceptance by the public (Fig. 3).

In this review we will address the contribution of proteomics to the study of the effects of stress in several farm animals including mammals (pigs, cows, small ruminants and rabbits), poultry, fish and shellfish (Fig. 4). We aim to present a general overview of this topic illustrated with specific study cases. The general subject of animal proteomics ${ }^{7}$ has been covered recently by several reviews see the special issue on Farm Animal Proteomics (http://www. sciencedirect.com/science/journal/18743919/75/14), and the assessment of animal welfare has also been recently reviewed. ${ }^{8-10}$

\section{Proteomics of cattle and nutritional stress: peripartum, negative energy balance and diseases (ketosis and fatty liver)}

The early lactation period of dairy cows is normally characterized by a status of negative energy balance (NEB), because the ingestion of 

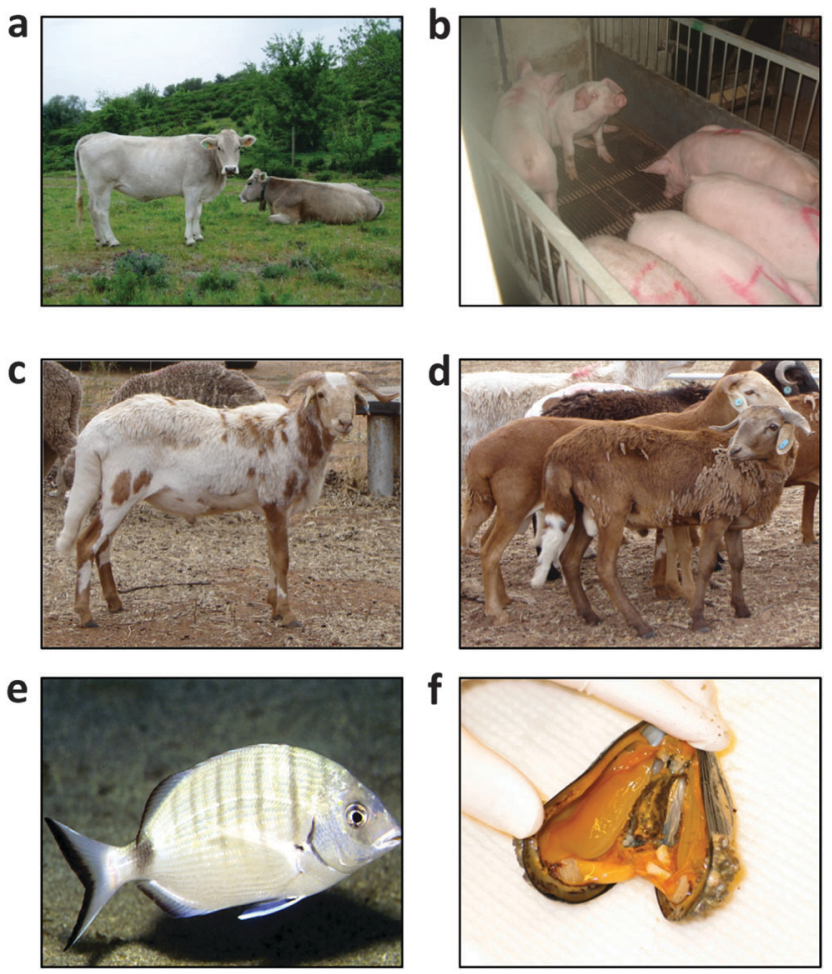

Fig. 4 Some of the animal species where proteomic studies have been published. (a) Cows from the Bruna dels Pirineus breed; (b) commercial pigs (duroc $\times$ (landrace $\times$ large white)); (c) and (d) the damara sheep breed; (e) gilthead seabream (Sparus aurata); (f) common mussel (Mytilus edulis).

nutrients and energy is insufficient to meet the energy demands of milk production. ${ }^{11}$ This transition period, defined as three weeks before parturition to three weeks postpartum, is characterized by the mobilization of body reserves from fat and muscle to compensate this NEB status. The consequence of lipid mobilization is an excessive concentration of free fatty acids in the blood, which in the liver are subjected to incomplete oxidation and reesterification. This situation results in ketosis and fatty liver, increased oxidative stress markers ${ }^{12}$ and hampered immune function, which lead to a higher susceptibility to diseases and metabolic disorders. ${ }^{13}$

Increased energy requirements lead to hypoglycemia which is compensated by lipid mobilization to the liver and further hepatic synthesis of ketone bodies, an energy fuel for many body tissues. Persistent ketosis is accompanied by acidosis, with unwanted consequences for animal welfare and health. Subclinical ketosis often affects $40 \%$ of the cows in a herd although the incidence can be up to $80 \%,{ }^{14}$ meaning that ketosis is one of the main problems in dairy cow production.

Due to the complexity of this physiological situation, several authors have approached it by using the available proteomic toolbox. Plasma from ketotic cows analyzed by 2DE and MALDITOF showed an increase in APPs such as haptoglobin, $\alpha$-1-acid glycoprotein (AGP) and $\alpha$-chymotrypsin and a decrease in other APPs such as Apolipoprotein-AIV and $\alpha$-2-HS-glycoprotein. ${ }^{15,16}$ These results on APP production were validated by iTRAQ (isobaric tag for relative and absolute quantification), a quantitative proteomic approach which employs differential labelling of up to eight protein samples thus allowing their simultaneous quantification. ${ }^{17}$ The enhanced sensitivity of iTRAQ also allowed the identification of cationic antimicrobial peptides, such as cathelicidin, in plasma, as well as an increased expression of the antioxidant enzyme glutathione peroxidase (GPx) and components of the complement and coagulation cascades (such as factor $V, \alpha 2$-antiplasmin and prothrombin), revealing the role of these pathways in inflammatory and immune responses. ${ }^{18}$

Since the liver is the main target in this condition, the ketotic liver proteome has also been analysed. By using 2DE and MALDI-TOF thirty-eight differential proteins involved in energy production, carbohydrate, fatty acid, amino acid and nucleotide metabolism, in oxidative stress and cell structure were identified. ${ }^{19}$ Furthermore, the liver proteome of ketotic cows was analysed by iTRAQ. Regulatory metabolic enzymes involved in the Krebs cycle and gluconeogenesis were deregulated during early lactation ${ }^{19}$ indicating the adaptation of the liver to cope with the metabolic imbalance.

Due to the lipid mobilization to the liver, sometimes there is an exaggerated deposit of lipids in this organ, causing the so called fatty liver. Apart from its intrinsic importance in dairy cow production, hepatic steatosis is closely associated with obesity, metabolic syndrome, and diabetic complications in humans, revealing the importance of such studies. This syndrome has been studied through proteomics by Kuhla and coworkers in a series of studies in non-pregnant Holstein cows subjected to nutrient (energy, macroand micronutrient) deprivation. To identify the liver proteins related to an energy-deficient status, the authors used a 2DE approach combined with MALDI-TOF and MALDI-TOF-TOF. ${ }^{20}$ In feedrestricted cows, there was an increase in liver total fat content accompanied by a decrease of glucose and glycogen concentrations, similar to the hepatic condition observed in dairy cows during the periparturient period. This is accompanied by an increase in the phosphorylation state of liver AMPK, a nutrient sensor and key regulator of cell signaling pathways involved in glycogen, fatty acid, steroid, and protein synthesis. ${ }^{21}$ The proteomic analysis showed that the enzymes of $\beta$-oxidation (oxidation of fatty acids) were down regulated after feed restriction suggesting a diminished degradation of fatty acids that might be one reason for the increased liver fat content. $^{20}$ Other proteins related to carbohydrate and protein metabolism, electron transport, calcium homeostasis, cytoskeleton structure and oxidative stress were also differentially identified in the proteomic analysis, presenting potentially novel candidates involved in signalling for metabolic adaptation to feed restriction and development of fatty liver.

This metabolic switch does not only happen in the liver but it also concerns other tissues such as the skeletal muscle since the animal mobilizes muscle protein to obtain amino acids that can be used for obtaining glucose via gluconeogenesis. An approach based on 2DE and MALDI-TOF identified forty-three differentially expressed muscular proteins leading to a decrease in glycogen synthesis and the TCA cycle, and an increase in proteins related to glycolysis, fatty acid degradation and lactate production, thus providing the Cori cycle with substrates for hepatic gluconeogenesis. ${ }^{22}$ 
Since feeding is controlled hormonally by the hypothalamuspituitary axis, the proteomes of these two structures have also been studied. ${ }^{11,22}$ The hypothalamus is the central regulatory unit that balances a number of body functions including the metabolic rate, hunger, and satiety signals in response to alterations in circulating nutrients and hormones. The authors studied the differential protein expression between hypothalami from ad libitum fed and energy restricted cows by 2-DE and MALDI-TOF-TOF and identified nine differentially expressed proteins related to energy and nucleotide metabolism, and cellular stress. ${ }^{11}$ A proteomic approach was also used to analyze the post-translational modifications (PTMs) underwent by the peptide pituitary hormones before secretion. Results indicated that changing plasma hormone concentrations is likely attributed to a regulated release process from the gland into the blood, and not to changes in PTM processing. ${ }^{23}$

Milk has also been used to search for simple and robust predictors of the NEB level due to its easy availability. Milk of cows subjected to different dry period lengths, in different energy balance status and lactation stages, were analysed by untargeted metabolomics and proteomics techniques. ${ }^{24}$ Milk of cows in severe NEB showed higher concentrations of APPs, unsaturated fatty acids, and galactose-1-phosphate, whereas improved energy balance resulted in higher concentration of cholesterol, cholesterol synthesis related proteins, and stomatin. As a result, the use of stomatin and galactose-1-phosphate as robust indicators of NEB in milk was suggested. ${ }^{24}$

A large part of the increased energy requirements during the early lactation comes from the mammary gland, which is subjected to a rapid growth and needs increased amounts of glucose for lactose production. The metabolic and developmental processes occurring in the mammary gland during lactation in the normal situation and in feed restricted cows have also been addressed through proteomics. ${ }^{25,26}$ The protein abundance in this tissue was consistent with fat synthesis rather than $\beta$-oxidation.

\section{Proteomics of cattle and management conditions}

Marco-Ramell and co-workers studied the adaptive physiological mechanisms in cows to harsh conditions in winter. Two groups of thirty Bruna dels Pirineus (Brown pyrenees) breeds a beef type selected from the Brown Swiss breed, were maintained during the winter under different living conditions: one group was maintained on a diet of improved pastures, whereas the second lived under semi-feral conditions. The serum proteomes from both groups were compared at the end of the winter period using DIGE (Differential Gel Electrophoresis) and MALDI-TOF. Fifteen spots could be identified as differentially expressed between both groups, including the antioxidant enzymes paraoxonase-1 and glutathione peroxidase 3 , some proteins related to the complement system, and the acute phase proteins $\alpha$-2-HSglycoprotein and the AMBP precursor. ${ }^{27}$ Some of these proteins were also determined in the serum of an additional group of thirty Albera cows, a beef breed that lives all the year under very harsh conditions. Therefore, proteomics revealed that living in hard environments in winter induces higher levels of oxidative stress and the activation of the immune system in cows.

Proteomics has also been extensively used in the search for disease biomarkers in cows. ${ }^{28,29}$ Although this topic is outside the scope of this review, it is interesting to report the study with -omics technologies aimed to differentiate stress and viral infection in cows. ${ }^{30}$ In this study, the authors used an experimental infection of bovine respiratory disease (BRD) in conjunction with the combined stressors of weaning, transportation, and social reorganization in young calves. BRD is a leading cause of morbidity and mortality in feedlot cattle and results from the combined infection of bacterial and viral agents. The stress of weaning, transportation and processing has long been known to play an important role in predisposing animals to BRD. Proteomic, metabolomic, and elemental profiles of serum samples from stressed and control animals were determined before and after a primary viral infection to test if these profiles could distinguish between responses to stressors and viral infection. Multivariate analysis was able to differentiate between a stress response (decreased serum amyloid A, increased apolipoprotein CIII, and other metabolomic changes) or a primary viral respiratory infection (increased apolipoprotein A1 and haptoglobin and others). Thus, combined -omics analysis of serum samples revealed that multimethod analysis could be used to discriminate between the complex biological responses to stress and viral infection.

Another proteomic study on stress and susceptibility to BRD was carried out in bronchi-alveolar fluid (BALF) which contains the secretory products and the remnants of the epithelial fluid of the lungs (ELF) and represents the first line of defence against inhaled opportunistic pathogens. ${ }^{31}$ The hypothesis to be tested was that stress would cause changes in the ELF of the lungs, thus being the cause of the increased susceptibility of this tissue to respiratory disease. The results showed increases in antioxidant enzymes such as superoxide dismutase (SOD) and GPx, and changes in the APPs ( $\alpha$-2-HS-glycoprotein, fibrinogen and annexin, amongst others).

A summary of the reported results for bovine proteomic studies is shown in Table S1 (ESI $\dagger$ ).

\section{Proteomics of pigs and different types of stress}

Pigs become easily stressed by many conditions. Management conditions such as housing, the establishment of social hierarchies, weaning, transport to the abattoir and lairage conditions, as well as the slaughterhouse are all potentially stressing factors for pigs. As described for cows, a high stress degree is associated with an increased incidence of disease, as well as deleterious effects on meat quality.

High stocking density is one of the most common and stressful conditions that affect growing and finishing pigs in commercial farms, as it combines social and thermal stress. Minimum space requirements have been stipulated by the European Council (2001) requiring a minimum stocking density; however, the space allowance during the latter part of the 
growing and the finishing periods would often fall below the current limits set out in this legislation. ${ }^{32}$ Marco-Ramell and co-workers carried out a 26 day experiment using 8 pigs which were subjected to 4 day periods of high $\left(0.25 \mathrm{~m}^{2}\right.$ per pig) and low $\left(0.5 \mathrm{~m}^{2}\right.$ per pig) stocking density. ${ }^{33}$ The differential expression of serum proteins was analysed by DIGE. Several spots were differentially expressed between low and high stocking density conditions, but only one spot could be identified by MALDI-TOF, corresponding to the cytoplasmatic $\beta$-actin, a component of the cytoskeleton. The identity of the protein was validated by western blot analysis in all the experimental individuals. The increase of actin in the serum might point out to cell or tissue damage associated with high stocking density.

Individual confinement of pregnant sows is another common and stressful housing system widely used under field conditions a few years ago, although it has been recently banned by the European Union (CD 66 2001/88/EC). MarcoRamell and co-workers used this housing model to identify new stress biomarkers before the actual legislation came into force. The serum proteome of gilts housed in groups and subjected to individual confinement was compared by using DIGE and iTRAQ. Individual confinement of gilts led to a complex physiological response that includes the activation of the immune system, changes in lipid mobilization, redox imbalance and cellular or tissue damage. ${ }^{34}$

\section{Proteomics, stress and meat quality}

Any cause of pre-slaughter stress affects meat quality. ${ }^{35,36} \mathrm{~A}$ well-known defect is a pale, soft and exudative appearance of meat (PSE or PSE-like meat). The phenomenon occurs essentially in pigs and also in poultry and was first described in Pietrain pigs carrying the halothane mutation affecting the Ryr gene. Nevertheless, the production of PSE-like meat can also occur in noncarriers, when animals are slaughtered following intense effort or stress. Stress causes the secretion of cortisol and catecholamines into the blood flow, which will exacerbate the degradation of glycogen, thus increasing muscle metabolic activity which may continue after death, resulting in higher lactic acid content and faster $\mathrm{pH}$ decline.

To identify proteins involved in the production of PSE meat, proteomes of pig semimembranosus muscles obtained $20 \mathrm{~min}$ post-mortem were compared between homozygous (nn) and heterozygous (Nn) carriers and non-carriers (NN) of the mutation. Muscles of the nn genotype appear to be less oxidative and to have less anti-oxidative and repair capacities than NN and Nn genotypes. Glyceraldehyde 3-phosphate dehydrogenase (GAPDH), an enzyme of the glycolytic pathway, has been proposed to be a good biomarker since it is indicative of higher proportions of fasttwitch glycolytic muscle fibres, which have a higher capacity to accelerate metabolism than slow-twitch oxidative fibres. Several heat shock proteins (HSPs) such as HSP72 and HSP27, which have multiple functions including protein stabilisation and repair, are increased after stress or exercise and can also be markers of meat quality development. $^{36}$

\section{The use of saliva as a convenient, non-invasive sample to assess stress}

Saliva is a very interesting fluid for biomarker discovery. It is easy to collect on a non-invasive and routine basis without any need for special training. It contains information about feeding status, nutritional requirements and adaptation to diet and environment, and the health status of animals. Therefore, the analysis of salivary proteomes is a field of high interest to search for livestock productivity, health and welfare biomarkers. Various analytes useful for stress monitoring, such as cortisol and some proteins, can be measured in saliva samples. ${ }^{37}$ In a recent study, pigs were subjected to 3 experimental models of acute stress: snaring restraint, brief transport by road and restriction of movement in a digestibility cage. The salivary proteome profiles before and after the experimental procedures were compared. Albumin and odorant-binding protein (OBP), a member of the lipocalin family, appeared to be down-regulated in all 3 groups after stress was applied, thus suggesting their potential use as a stress biomarker. ${ }^{38}$

A summary of the reported results for porcine proteomic studies is shown in Table S2 (ESI $\dagger$ ).

\section{Proteomics and seasonal weight loss (SWL)-induced stress}

Mediterranean and tropical climates are characterized by an uneven distribution of rain, leading to two seasons: rainy and dry. The first is characterized by high temperatures, high rainfall and higher pasture quality, the latter is characterized by the opposite. During the dry season, ruminant production is severely affected and animals undergo a period of feed restriction leading to Seasonal Weight Loss (SWL), one of the most pressing issues in animal production, affecting animal production e.g. in Southern and Western Africa, ${ }^{39,40}$ Western Australia ${ }^{41}$ and the Canary Islands. ${ }^{42}$ To counter SWL, several strategies have been tried, from supplementation with purchased feeds to others more innovative such as the use of antibodies blocking the action of the hormone leptin, ${ }^{43}$ aiming at the increase of feed intake before the onset of feed restriction. Another alternative could be the use of breeds well adapted to SWL, for instance fat-tailed sheep ${ }^{44}$ such as Damara ${ }^{45}$ able to produce in harsh environments but having lower productivity and commercial value. It is therefore of utmost importance to understand the molecular mechanisms by which such breeds have evolved to adapt to SWL by establishing molecular markers of tolerance to SWL and use this information for animal selection. As meat and milk are important outputs of animal production, and proteinaceous products, proteomics assumes a major role in their definition, as recently reviewed for meat ${ }^{46,47}$ and milk. ${ }^{48,49}$ With the exception of the pig, ${ }^{50}$ cow $^{51}$ and rabbit, ${ }^{52}$ proteomics studies are more complicated in farm animal species due to the low representation in protein databases than classical model species such as cattle or pig that are fully sequenced or well represented. $^{53}$ 
The establishment of biomarkers of tolerance to SWL could be accomplished either by studying the metabolic effects of feed restriction or by comparing SWL tolerant and sensitive breeds. Proteomics has been used to work on this topic over the last 20 years, using at an initial phase the first strategy and more recently the latter. At an initial phase, and before the advent of standard proteomics techniques, serum amino acid analysis and one-dimensional protein electrophoresis (1DE) were used to study the effect of weight loss in rats ${ }^{43}$ and goat bucks, ${ }^{54,55}$ in parallel with an insight into fatty acid metabolism, ${ }^{56,57}$ linked to production parameters. ${ }^{39}$ These were the first studies concerning for instance the myofibrillar protein profile in the muscle and as a consequence of SWL. These studies constituted the first "proto-proteomics" approach for the study of nitrogen metabolism in SWL defining interesting implications for supplementation ${ }^{54}$ and confirming that the amino acid 3-methylhistidine is an indicator of protein breakdown and muscle disruption in goat. ${ }^{55}$

Proteomics was first used to study the adaptations of certain breeds to SWL for the first time comparing the muscle proteome in two breeds of rabbits, the New Zealand White rabbit (susceptible to SWL) and the Iberian wild rabbit, adapted to SWL, first using one-dimensional electrophoresis ${ }^{58}$ and later using two-dimension electrophoresis. ${ }^{59}$ Results pointed out significant differences between the ways both breeds reacted to weight loss, particularly showing that enzymes L-lactate dehydrogenase, adenylate kinase, and glyceraldehyde 3-phosphate dehydrogenase were differentially expressed in restricted diet experimental animal groups and could be potential relevant biomarkers of weight loss tolerance in addition to mapping the rabbit muscle proteome $\mathrm{e}^{60}$ that was recently complemented using shotgun proteomics. ${ }^{61,62}$

Subsequently, a study at the level of the liver and muscle proteomes in three sheep breeds with different levels of adaptation to nutritional stress was conducted: Damara, Dorper and Australian Merino. Damara is a fat-tailed breed originating from the semi-arid regions of Namibia and South Africa highly resilient to SWL with a notable ability to digest poor quality fodder $^{45}$ and a particular lipid metabolism leading to the accumulation of branched chain fatty acids. ${ }^{63}$ The other two breeds, Dorper and Australian Merino, are less adapted to SWL than Damara. The three breeds were subjected to nutritional stress over a period of 42 days, leading to relative live weight decreases of about $10-15 \%{ }^{64}$ and meat and carcass traits were studied $^{62}$ as well as the muscle fatty acid profiles, ${ }^{65}$ as well as in-depth characterization of the fatty acid profile of the fat tail $^{63}$ and mineral profiles ${ }^{66}$ of the adipose tissue. Regarding proteomics, 2DE coupled to MS/MS mass spectrometry was used to identify proteins differentially expressed in the muscle ${ }^{67}$ and the liver. ${ }^{68}$ Results point to differential expression profiles between the liver and the muscle in the three breeds and several proteins could be considered as biomarker candidates for the tolerance to weight loss: glutathione $S$-transferase, phosphoglycerate mutase, and a HSP-like stress protein (liver) histidine triad nucleotide-binding protein, desmin, and phosphoglucomutase-1, (muscle). ${ }^{69}$ Recently, shotgun proteomics was performed also using the samples arising from the trial previously described. ${ }^{70}$
The authors identified 685 proteins in the ovine skeletal muscle, of which 17 could be proposed as markers of tolerance to SWL: apolipoprotein A-IV, ferritin heavy polypeptide 1, and serpin peptidase inhibitor clade $\mathrm{H}$ member 1 . Shotgun proteomics (iTRAQ) was used to study changes in the wool proteome in the Australian Merino animals used in this study ${ }^{71}$ showing that SWL decreases the fibre diameter increasing the expression of high sulphur protein KAP13.1 and proteins from the high glycinetyrosine protein KAP6 family, with implications on wool quality. More recently, proteomics was used to study tolerance to SWL in dairy goats, by comparing breeds from the Canary Islands with different levels of adaptation to nutritional stress. ${ }^{42}$ Biopsy samples from the mammary gland secretory tissue were obtained and the mitochondrial proteome was characterized using two-dimensional electrophoresis and Blue Native PAGE techniques ${ }^{72}$ and differences regarding protein expression between the two breeds were determined. These samples were also used to conduct the first NMR-metabolomics study on the goat mammary gland, showing high complementarity between these two techniques with NMRbased metabolomics being able to quantify low molecular weight metabolites. $^{73}$

These above-mentioned results indicate the importance of proteomics techniques and systems biology in the discovery of markers of tolerance to seasonal weight loss and their use within the context of farm animal breeding aiming to circumvent problems related to SWL.

A summary of the reported results for seasonal weight lossinduced stress proteomic studies is shown in Table S3 (ESI $\dagger$ ).

\section{Proteomics in poultry stress research}

Proteomics techniques have seldom been used in stress-related studies in poultry, with the exception of restraint and transport, ${ }^{74}$ heat stress, ${ }^{75,76}$ obesity-induced stress ${ }^{77}$ and stress related to diseases and pathological conditions.

Stress induced by immobility, transport and slaughter processes are among the most pressing issues addressed by the poultry industry. Poultry production can be characterized as extremely intensive and upon the completion of the production cycle, animals are captured, kept in cages with other animals and transported by road to the abattoir facing meteorological conditions, restraint, lack of food and water in a process that may take several hours. All these steps are attentively scrutinized and governed by specific legislation aiming to minimize stress being attentively scrutinized by public opinion and consumer organizations. Poultry stress under transport conditions has been the subject of numerous studies. ${ }^{78}$ In 2011, Hazard and co-workers conducted a multi-Omics approach (transcriptomics, proteomics and metabolomics) to study the effects of restraining transport on molecular mechanisms on chicken thigh muscle by comparing 6 week old 2 h-restrained and control chickens. Road transport induced stress led to increase in the levels of corticosterone, whilst decreased the abundance of several hexose phosphates, increased and decreased 
the expression of respectively 12 and 27 transcripts, as well as the overexpression of 11 proteins and the underexpression of 14 proteins, finally concluding that road transport affected cytoskeleton structure and carbohydrate metabolism. Interestingly, authors found that induced stress led to a repression of glycogenolysis and glycolysis and an alteration of the myofibrillar protein $^{\text {profile. }}{ }^{74}$

Heat stress is another important aspect in poultry production compromising feed intake, conversion rates and increasing susceptibility to diseases and parasites and mortality rates. Zeng et al. ${ }^{75}$ studied the effects of heat stress on the liver proteome of Peking (Anas platyrhynchos) and Muscovy (Cairina Moschata) ducks, with the first being considered as more susceptible to heat stress than the latter. The authors used a proteomics approach based on two-dimensional electrophoresis and protein identification using mass spectrometry. They identified 54 proteins, of which only seven were found in both species and 47 were actually species specific. Proteins such as heat shock proteins 70 and 10 were clearly over-expressed in both species in response to heat stress and other proteins like $\alpha$-enolase and $S$-adenosylmethionine synthetase showed a different expression pattern between the two species, finally revealing that in both species heat stress affected the glycolytic pathway whereas in the Muscovy duck, processes such as antigen processing and presentation and apoptosis seem to affect essentially the latter. ${ }^{75}$ An approach using two-dimensional electrophoresis, specifically DIGE, has also been used to study the effect of AHS - Acute Heat Stress ( 4 hours at $38{ }^{\circ} \mathrm{C}$ ) on the testis proteome, and on fertility levels, of Taiwanese roosters. ${ }^{76}$ Acute heat stress led to abnormal, apoptotic spermatogenic cells, and to 119 protein spots being differentially expressed. AHS also led to an upregulation of proteins like glutathione $S$-transferase, transgelin, and DJ-1 and to a down-regulation of proteins such as heat shock proteins, chaperonin containing t-complexes, and proteasome subunits, showing that heat stress has an important effect on protein folding and degradation linked to spermatogenesis, whereas proteins with antioxidant properties could attenuate heat-stress consequences in chickens. ${ }^{76}$

Another area in which proteomics has been successively used to study the effects of stress in poultry is the determination of the fat deposition ability ${ }^{77}$ and foie-gras production related steatosis ${ }^{79}$ in ducks. The subject has been reviewed, ${ }^{80}$ hence we will only focus here on aspects directly related to stress itself. As previously stated steatosis is abnormal intracellular retention of lipids. It has a strong genetic correlation to certain geese and duck genotypes used in foie gras (fatty liver) production. Bax et al. ${ }^{79}$ used 2DE to compare different stages of steatosis. The authors showed that the process leads to significant changes in protein expression at various levels including enzymes, translation factors, proteins involved in cell structure, proteins with antioxidant properties, and calcium linking proteins, establishing the first evolutional study on the protein profiles of waterfowl livers as a consequence of hypercaloric force feeding. Similarly, and also using $2 \mathrm{DE}$, Zheng et al. $^{77}$ compared the liver proteomes of two strains of Peking ducks differing in the ability to depose fat, at different ages. The authors discovered that fat ducks had an over-expression of proteins related to glycolysis, ATP synthesis, and protein catabolism in a process very similar to the one previously described for foie gras production, whereas the lean strain had a higher expression of proteins leading to increased protein anabolism and reduced catabolism, as well as the over expression of proteins related to stress response, immune defence, and antioxidant functions.

As described above, in recent years the potential of proteomics studies in stress-related issues in poultry has hardly been tapped. In fact the examples shown demonstrate that proteomics-based studies can be of significance in the determination of biomarkers of avian welfare, product quality under stressful production conditions or even the determination of markers of tolerance to stress conditions such as those related to temperature stress, particularly heat.

A summary of the reported results for stress proteomic studies in poultry is shown in Table S4 (ESI $\dagger$ ).

\section{Proteomics and stress in farmed fish and seaclams}

Aquaculture refers to all forms of active culturing of aquatic animals and plants, occurring in marine, brackish, or fresh waters. According to FAO's last report ${ }^{81}$ global aquaculture production attained another all-time high of 90.4 million tonnes in 2012. Aquaculture production is focused on 3 main sectors: fish, with a volume of 44.15 million tons in 2012, representing $66.3 \%$ of production; molluscs with 15.17 million tons equivalent to $22.8 \%$, and crustaceans, 6.44 million tons, 9.7\%. Fish accounts for about 17 percent of the global population's intake of animal protein.

The tremendous growth of this industry has been stimulated by the intrinsic limitations to the productivity of the wild, unmanaged aquatic ecosystems overexploited by humans as sources of fish, aquatic invertebrates and seaweeds, with harvest yields declining substantially over the last few decades. The modern aquaculture is driven by improving the sustainability of production and it is based on scientific knowledge such as genetic information, ${ }^{82,83}$ improving fish health and nutrition, welfare assessment and stress reduction, diseases and the use of antibiotics and vaccines.

Fish and seaclams welfare and stress are important issues in aquaculture mainly because of public perception, marketing, product acceptance, and production efficiency, quality and quantity. Fish are vertebrates and thought to share many traits in common with the more familiar intensively farmed animals such as pigs, chickens or cows. However, due to the separate evolutionary history and different adaptation needs, they have a number of special features that are relevant to the way welfare is approached. Fish welfare is in that sense a complex concept, which underlines the importance of a multidisciplinary and holistic approach in its studies. Proteomics can therefore be an important part of the toolset required for such studies, ensuring that marine animals are reared in an environment that optimizes their capacity to cope with unavoidable challenges/stress. ${ }^{84}$ 
Also it is important to understand that stress responses will not provide all the necessary information about fish welfare, since in aquaculture the latter is largely associated with tertiary effects of stress response that are generally indicative of prolonged, repeated or unavoidable stress ${ }^{85,86}$ that is mostly related to deleterious effects on growth, reproductive function, immune function and disease resistance. ${ }^{87}$ In seaclams, the stress response should be understood in the context of their physiology and as a consequence of diseases. They are sessile, filter feeders capable of accumulating high levels of contaminants, affected by the temporally and spatially integrated levels of contamination in the environment. ${ }^{88}$ Mollusc diseases include parasitic, bacterial or virus infections and it may have a very serious effect on the shellfish industry. ${ }^{89}$ There are 5 main mollusc species, all bivalves, produced in aquaculture corresponding to 3 clams: Ruditapes philippinarum (Japanese clam), Anadara granosa (Blood clam), and Sinonovacula constricta (Chinese clam), oyster Crassostrea gigas (Pacific oyster), and Mytilus chilensis (Chilean mussel).

Proteomics studies of aquaculture and welfare are mostly focused on the health aspects of the animal tissues. In fish, organs/tissues/fluids like the liver, brain, skeletal muscle, blood plasma and osmorregulatory and immune-related organs have been extensively studied. ${ }^{92-130}$ The liver has a central role in metabolic processes and blood plasma, due to its non-evasive collection, and it is by far the most informative source. In seaclams, the digestive glands, gills and gonads are the studied tissues as well as haemolymph, main body fluid in the open circulatory system of molluscs that is functionally equivalent to blood and lymph in vertebrates. ${ }^{90}$

Aquaculture production is a factor of stress induction as it involves management practices and environmental sources with influences on fish welfare. Proteome changes in several tissues have been reported in fish subjected to high stocking densities, ${ }^{91,92}$ handling, ${ }^{91,93}$ pre-slaughter stress, ${ }^{94,95}$ hypoxia, ${ }^{96,97}$ anoxia, ${ }^{98-100}$ hyperoxygenation ${ }^{101}$ and osmotic ${ }^{102-105}$ and temperature changes. ${ }^{106-108}$ Also proteomics has been used as an attempt to establish welfare biomarkers in farmed fish ${ }^{91,109,110}$ with several proteins identified. In molluscs, proteome changes associated with hypoxia-induced stress caused by aerial exposure altered metabolic responses or eutrophication, ${ }^{88,111,112}$ hypersalinity, ${ }^{111,113-115}$ and temperature variations. ${ }^{113,116,117}$

Another important research subject in aquaculture targeted by proteomics concerns the impact of xenobiotics on farmed fish and seaclams. Many chemicals of different origins are being released into the environment on a regular basis, entering in many cases the effluent of wastewater treatment plants and aquatic environments. ${ }^{118}$ As many of these chemicals are relatively stable to sewage treatment, its effect when entering the aquatic environments can trigger toxic reactions in non-target species. These can affect not only exposed farmed marine species but also humans via their consumption. Reported studies are mostly focused on the impact on the proteome of fish exposed to pharmaceuticals, ${ }^{119,120}$ hormones, ${ }^{121,122}$ metals, ${ }^{123,124}$ bioxantines $^{125-127}$ and other pollutants. ${ }^{109,128,129}$ The impact of xenobiotics on molluscs has been extensively studied both in the laboratory and in field exposure to environmental pollutants, ${ }^{88,112,130-140}$ exposure to pharmaceuticals, $^{141,142}$ toxins ${ }^{127,143-148}$ and cyanobacteria. ${ }^{145,147}$

Finally, the research area where most fish proteomics studies have been reported concerns health aspects. Several types of proteome analyses as a result of viral diseases, ${ }^{149-155}$ bacterial diseases, ${ }^{138,149,156-161}$ tumors, ${ }^{162}$ skeletal deformities ${ }^{163}$ and parasite exposure ${ }^{125}$ have been published on farmed fish. An important study has also been reported on vaccine development. ${ }^{164-172}$ On the other hand molluscs proteomics studies focused on health and infections have recently attracted attention. ${ }^{89,138,173-175}$

Another important field of aquaculture where proteomics studies have been reported recently relates to fish nutrition. Due to the increasing demand for fish oil and fish meal in aquafeeds, more sustainable alternatives to the traditional diet formulations, such as plant-derived oils and proteins, are emerging. Interestingly, a few papers report the fish proteome response to these new fish meals, as a new insight into the response of fish metabolism to dietary substitutions. ${ }^{176-180}$ Also the impact on the fish proteome of specific diet formulations, formulated to mitigate disease effects, has been reported. ${ }^{181}$

Proteomic analysis of bivalves has evolved from requiring efforts and costs to identify few proteins from 2-DE maps ${ }^{130}$ to a systematic quantitative analysis of all cellular proteins in a single experiment. ${ }^{90,182}$ In the near future proteomic based methods would not only provide robust information to improve aquaculture welfare but also could be utilized for screening new biotechnological products and novel food sources derived from marine proteins, ${ }^{183}$ and meta-proteomic approaches will also contribute to water quality assessment in aquaculture ${ }^{7}$ by monitoring the dynamics of the aquatic sediment microbiome. ${ }^{184}$

A summary of the reported results for stress proteomic studies in fish and clams is shown in Table S5 (ESI $\dagger$ ).

\section{Conclusions}

Proteins have a leading role in all physiological processes and some of them may be useful as potential markers of these processes. Animal stress and welfare are aspects of the utmost importance in animal production, but objective and quantitative laboratory markers are still lacking. Proteomics has the strength and versatility and it is a non-hypothesis driven approach most adequate for the identification of new biomarkers. Nowadays, there is a growing awareness about the suitability of proteomic approaches to the investigation of the proteins produced by farm animals, and there are more and more links being established between animal science and technological based proteome centres. This will allow this field to expand at a rapid rate in the immediate future, with a major impact on the scientific knowledge of farm animals, including all aspects related to stress and welfare, and also on the economically important production of livestock and aquaculture systems.

\section{Acknowledgements}

The authors would like to thank all the colleagues and the funding agencies that have contributed and supported research 
on farm animal proteomics. Especially, the authors are most grateful to COST Action FA1002 - Farm Animal Proteomics which has led to the productive interaction of all co-authors of this review.

\section{References}

1 P. Roncada, A. Modesti, A. M. Timperio, L. Bini, M. Castagnola, M. Fasano and A. Urbani, Mol. BioSyst., 2014, 10, 1226-1227.

2 A. Bassols, R. Turk and P. Roncada, Curr. Protein Pept. Sci., 2014, 15, 156-168.

3 D. M. Broom, J. Vet. Med. Educ., 2010, 37, 83-88.

4 I. Messana, T. Cabras, F. Iavarone, F. Vincenzoni, A. Urbani and M. Castagnola, J. Sep. Sci., 2013, 36, 128-139.

5 Y.-T. Wen, J.-S. Wang, S.-H. Tsai, C.-N. Chuan, J.-J. Wu and P.-C. Liao, J. Proteomics, 2014, 109, 90-103.

6 P. Mormede, S. Andanson, B. Auperin, B. Beerda, D. Guemene, J. Malmkvist, X. Manteca, G. Manteuffel, P. Prunet, C. G. van Reenen, S. Richard and I. Veissier, Physiol. Behav., 2007, 92, 317-339.

7 A. M. Almeida, A. Bassols, E. Bendixen, M. Bhide, F. Ceciliani, S. Cristobal, P. D. Eckersall, K. Hollung, F. Lisacek, G. Mazzucchelli, M. McLaughlin, I. Miller, J. E. Nally, J. Plowman, J. Renaut, P. Rodrigues, P. Roncada, J. Staric and R. Turk, Animal, 2015, 9, 1-17.

8 D. Fraser, I. J. H. Duncan, S. A. Edwards, T. Grandin, N. G. Gregory, V. Guyonnet, P. H. Hemsworth, S. M. Huertas, J. M. Huzzey, D. J. Mellor, J. A. Mench, M. Spinka and H. R. Whay, Vet. J., 2013, 198, 19-27.

9 S. E. Place and F. M. Mitloehner, Annu. Rev. Anim. Biosci., 2014, 2, 555-569.

10 P. H. Hemsworth, D. J. Mellor, G. M. Cronin and A. J. Tilbrook, N. Z. Vet. J., 2015, 63, 24-30.

11 B. Kuhla, S. Kuhla, P. E. Rudolph, D. Albrecht and C. C. Metges, Proteomics, 2007, 7, 3602-3617.

12 R. Turk, D. Juretic, D. Geres, A. Svetina, N. Turk and Z. Flegar-Mestric, Anim. Reprod. Sci., 2008, 108, 98-106.

13 J. J. Loor, M. Bionaz and J. K. Drackley, Annu. Rev. Anim. Biosci., 2013, 1, 365-392.

14 J. A. A. McArt, D. V. Nydam, G. R. Oetzel, T. R. Overton and P. A. Ospina, Vet. J., 2013, 198, 560-570.

15 F. Cairoli, M. Battocchio, M. C. Veronesi, D. Brambilla, F. Conserva, I. Eberini, R. Wait and E. Gianazza, Electrophoresis, 2006, 27, 1617-1625.

16 Y. X. Yang, J. Q. Wang, D. P. Bu, S. S. Li, T. J. Yuan, L. Y. Zhou, J. H. Yang and P. Sun, Czech J. Anim. Sci., 2012, 57, 481-489.

17 T. Guo, C. S. Gan, H. Zhang, Y. Zhu, O. L. Kon and S. K. Sze, J. Proteome Res., 2008, 7, 4831-4840.

18 L. Ma, D. Bu, Y. Yang, S. Yan and J. Wang, J. Integr. Agric., 2015, 14, 1407-1413.

19 K. M. Moyes, E. Bendixen, M. C. Codrea and K. L. Ingvartsen, J. Dairy Sci., 2013, 96, 3599-3610.

20 B. Kuhla, D. Albrecht, S. Kuhla and C. C. Metges, Physiol. Genomics, 2009, 37, 88-98.
21 B. Viollet, B. Guigas, J. Leclerc, S. Hébrard, L. Lantier, R. Mounier, F. Andreelli and M. Foretz, Acta Physiol., 2009, 196, 81-98.

22 B. Kuhla, G. Nürnberg, D. Albrecht, S. Görs, H. M. Hammon and C. C. Metges, J. Proteome Res., 2011, 10, 4252-4262.

23 B. Kuhla, D. Albrecht, R. Bruckmaier, T. Viergutz, G. Nurnberg and C. C. Metges, Proteomics, 2010, 10, 4491-4500.

$24 \mathrm{~J} . \mathrm{Lu}$, E. Antunes Fernandes, A. E. Páez Cano, J. Vinitwatanakhun, S. Boeren, T. van Hooijdonk, A. van Knegsel, J. Vervoort and K. A. Hettinga, J. Proteome Res., 2013, 12, 3288-3296.

25 P. Rawson, C. Stockum, L. Peng, B. Manivannan, K. Lehnert, H. E. Ward, S. D. Berry, S. R. Davis, R. G. Snell, D. McLauchlan and T. W. Jordan, J. Proteomics, 2012, 75, 4429-4435.

26 K. M. Daniels, K. E. Webb Jr, M. L. McGilliard, M. J. Meyer, M. E. Van Amburgh and R. M. Akers, J. Dairy Sci., 2006, 89, 4276-4288.

27 A. Marco-Ramell, L. Arroyo, Y. Saco, A. Garcia-Heredia, J. Camps, M. Fina, J. Piedrafita and A. Bassols, J. Proteomics, 2012, 75, 4399-4411.

28 F. Ceciliani, J. J. Ceron, P. D. Eckersall and H. Sauerwein, J. Proteomics, 2012, 75, 4207-4231.

29 M. Danielsen, M. C. Codrea, K. L. Ingvartsen, N. C. Friggens, E. Bendixen and C. M. Røntved, Proteomics, 2010, 10, 2240-2249.

30 P. Aich, S. Jalal, C. Czuba, G. Schatte, K. Herzog, D. J. Olson, A. R. Ross, A. A. Potter, L. A. Babiuk and P. Griebel, OMICS, 2007, 11, 413-434.

31 G. B. Mitchell, M. E. Clark, M. Siwicky and J. L. Caswell, Vet. Immunol. Immunopathol., 2008, 125, 111-125.

32 A. B. G. Leek, B. T. Sweeney, P. Duffy, V. E. Beattie and J. V. O'Doherty, Anim. Sci. Int. J. Fundam. Appl. Res., 2004, 79, 109-119.

33 A. Marco-Ramell, R. Pato, R. Pena, Y. Saco, X. Manteca, J. L. Ruiz de la Torre and A. Bassols, Vet. J., 2011, 190, e66-e71.

34 A. Marco-Ramell, L. Arroyo and A. Bassols, Proceedings of the 3rd Meeting of COST Action 1002, Wageningen Academic Press, Wageningen, NL, 2013, pp. 40-42.

35 A. Kwasiborski, T. Sayd, C. Chambon, V. Santé-Lhoutellier, D. Rocha and C. Terlouw, Meat Sci., 2008, 80, 982-996.

36 B. Picard, C. Berri, L. Lefaucheur, C. Molette, T. Sayd and C. Terlouw, Briefings Funct. Genomics, 2010, 9, 259-278.

37 E. Lamy and M. Mau, J. Proteomics, 2012, 75, 4251-4258.

38 M. Fuentes-Rubio, J. J. Cerón, C. de Torre, D. Escribano, A. M. Gutiérrez and F. Tecles, Can. J. Vet. Res., 2014, 78, 127-132.

39 A. M. Almeida, L. M. Schwalbach, H. O. de Waal, J. P. C. Greyling and L. A. Cardoso, Trop. Anim. Health Prod., 2006, 38, 443-449.

40 R. M. de Almeida, P. F. Ferrari, S. Parmigiani and K. A. Miczek, Eur. J. Pharmacol., 2005, 526, 51-64.

41 A. M. Almeida, T. Kilminster, T. Scanlon, S. S. Araújo, J. Milton, C. Oldham and J. C. Greeff, Trop. Anim. Health Prod., 2013, 45, 1305-1311.

42 J. R. Lérias, L. E. Hernández-Castellano, A. MoralesDelanuez, S. S. Araújo, N. Castro, A. Argüello, J. Capote 
and A. M. Almeida, Trop. Anim. Health Prod., 2013, 45, 1731-1736.

43 A. Almeida and L. Cardoso, Scand. J. Lab. Anim. Sci., 2002, 29, 65-68.

44 A. M. Almeida, Trop. Anim. Health Prod., 2011, 43, 1233-1235. 45 A. M. Almeida, Trop. Anim. Health Prod., 2011, 43, 1427-1441. 46 G. Paredi, M.-A. Sentandreu, A. Mozzarelli, S. Fadda, K. Hollung and A. M. de Almeida, J. Proteomics, 2013, 88, 58-82.

47 G. Paredi, S. Raboni, E. Bendixen, A. M. de Almeida and A. Mozzarelli, J. Proteomics, 2012, 75, 4275-4289.

48 P. Roncada, C. Piras, A. Soggiu, R. Turk, A. Urbani and L. Bonizzi, J. Proteomics, 2012, 75, 4259-4274.

49 P. Roncada, L. H. Stipetic, L. Bonizzi, R. J. S. Burchmore and M. W. Kennedy, J. Proteomics, 2013, 88, 47-57.

50 A. M. de Almeida and E. Bendixen, J. Proteomics, 2012, 75, 4296-4314.

51 A. M. Ferreira, S. L. Bislev, E. Bendixen and A. M. Almeida, J. Proteomics, 2013, 94C, 110-123.

52 I. Miller, C. Rogel-Gaillard, D. Spina, L. Fontanesi and A. M. de Almeida, Curr. Protein Pept. Sci., 2014, 15, 134-145.

53 R. Soares, C. Franco, E. Pires, M. Ventosa, R. Palhinhas, K. Koci, A. Martinho de Almeida and A. Varela Coelho, J. Proteomics, 2012, 75, 4190-4206.

54 A. M. Almeida, L. M. J. Schwalbach, H. O. deWaal, J. P. C. Greyling and L. A. Cardoso, Small Rumin. Res., 2004, 55, 141-147.

55 A. Almeida, L. Schwalbach, H. DeWaal, J. Greyling and L. Cardoso, Scand. J. Lab. Anim. Sci., 2008, 35, 259-263.

56 S. Van Harten, A. Almeida, Z. Morais and L. Cardoso, Nutr. Res., 2003, 23, 1685-1690.

57 S. Van Harten, A. Almeida, Z. Morais, L. Schwalbach, J. Greyling, H. de Waal and L. Cardoso, Nutr. Res., 2003, 23, 1447-1452.

58 A. M. Almeida, S. van Harten, A. Campos, A. V Coelho and L. A. Cardoso, J. Anim. Physiol. Anim. Nutr., 2010, 94, 174-185.

59 A. M. Almeida, A. Campos, R. Francisco, S. van Harten, L. A. Cardoso and A. V. Coelho, Anim. Genet., 2010, 41, 260-272.

60 A. M. Almeida, A. Campos, S. van Harten, L. A. Cardoso and A. V. Coelho, Res. Vet. Sci., 2009, 87, 196-199.

61 Z. Liu, X. Du, C. Yin and Z. Chang, Proteomics, 2013, 13, 2335-2338.

62 A. M. de Almeida, Proteomics, 2013, 13, 2225-2226.

63 S. P. Alves, R. J. B. Bessa, M. A. G. Quaresma, T. Kilminster, T. Scanlon, C. Oldham, J. Milton, J. Greeff and A. M. Almeida, PLoS One, 2013, 8, e77313.

64 T. T. Scanlon, A. M. Almeida, A. van Burgel, T. Kilminster, J. Milton, J. C. Greeff and C. Oldham, Small Rumin. Res., 2013, 109, 101-106.

65 S. van Harten, T. Kilminster, T. Scanlon, J. Milton, C. Oldham, J. Greeff and A. M. Almeida, J. Sci. Food Agric., 2015, DOI: $10.1002 /$ jsfa.7285.

66 J. Lerias, T. Kilminster, T. Scanlon, J. Milton, C. Oldham, J. Greeff, L. L. Martins, M. Mourato and A. Almeida, Anim. Prod. Sci., 2015, DOI: 10.1071/AN14852.
67 A. Almeida, R. Palhinhas, T. Kilminster, T. Scanlon, S. van Harten, J. Milton, D. Blache, J. Greeff, C. Oldham, A. Coelho and L. Cardoso, PLoS One, 2016, 11, e0146367.

68 A. Almeida, M. Carvalho, C. Franco, R. Francisco, T. Kilminster, T. Scanlon, J. Greef, J. Milton, C. Oldham, L. Cardoso and A. Coelho, in 4th EuPA Scientific Meeting - A Proteomics Odyssey Towards Next Decades, ed. G. Marko-Varga and T. Simoes, EUPA, Estoril, PT, 2010, pp. 612-613.

69 A. Almeida, R. Palhinhas, T. Kilminster, T. Scanlon, J. Greeff, C. Oldham, J. Milton, A. Coelho and L. Cardoso, in Proceedings of the Meeting of COST Action 1002, ed. P. Rodrigues, P. Eckersall and A. Almeida, Wageningen Academic Press, Wageningen, NL, 2012, pp. 126-129.

70 A. Ferreira, P. Nanni, T. Kilminster, T. Scanlon, J. Milton, J. Greeff, C. Oldham and A. Almeida, Proceedings of the COST Action FA1002, 2014, pp. 271-273.

71 A. M. Almeida, J. E. Plowman, D. P. Harland, A. Thomas, T. Kilminster, T. Scanlon, J. Milton, J. Greeff, C. Oldham and S. Clerens, J. Proteomics, 2014, 103, 170-177.

72 G. Cugno, L. Hernandez-Castellano, M. Carneiro, N. Castro, A. Arguello, J. Capote, S. Planchon, J. Renaut, A. Campos and A. Almeida, Proceedings of the COST Action FA1002, 2014, pp. 128-130.

73 M. Palma, M. Matzapetakis and A. Almeida, Proceedings of the COST Action FA1002, 2014, pp. 103-105.

74 D. Hazard, X. Fernandez, J. Pinguet, C. Chambon, F. Letisse, J.-C. Portais, Z. Wadih-Moussa, H. Rémignon and C. Molette, J. Anim. Sci., 2011, 89, 2717-2730.

75 T. Zeng, X. Jiang, J. Li, D. Wang, G. Li, L. Lu and G. Wang, PLoS One, 2013, 8, e76917.

76 S.-H. Wang, C.-Y. Cheng, C.-J. Chen, H.-H. Chen, P.-C. Tang, C.-F. Chen, Y.-P. Lee and S.-Y. Huang, Theriogenology, 2014, 82, 80-94.

77 A. Zheng, W. Chang, S. Hou, S. Zhang, H. Cai, G. Chen, R. Lou and G. Liu, J. Proteomics, 2014, 98, 271-288.

78 K. S. Schwartzkopf-Genswein, L. Faucitano, S. Dadgar, P. Shand, L. A. González and T. G. Crowe, Meat Sci., 2012, 92, 227-243.

79 M. L. Bax, C. Chambon, N. Marty-Gasset, H. Remignon, X. Fernandez and C. Molette, Poult. Sci., 2012, 91, 112-120.

80 C. Molette, L. Théron, N. Marty-Gasset, X. Fernandez and H. Rémignon, J. Proteomics, 2012, 75, 4290-4295.

81 The State of World Fisheries and Aquaculture. Food and Agriculture Organization of the United Nations, 2014.

82 M. P. Astorga, Front. Genet., 2014, 5, 1-6.

83 W. H. Eldridge, J. J. Hard and K. A. Naish, Ecol. Appl., 2010, 20, 1936-1948.

84 P. M. Rodrigues, T. S. Silva, J. Dias and F. Jessen, J. Proteomics, 2012, 75, 4325-4345.

85 B. A. Barton, Integr. Comp. Biol., 2002, 42, 517-525.

86 F. S. Conte, Appl. Anim. Behav. Sci., 2004, 86, 205-223.

87 P. J. Ashley, Appl. Anim. Behav. Sci., 2007, 104, 199-235.

88 I. Apraiz, J. Mi and S. Cristobal, Mol. Cell. Proteomics, 2006, 5, 1274-1285.

89 S. Castellanos-Martínez, A. P. Diz, P. Álvarez-Chaver and C. Gestal, J. Proteomics, 2014, 105, 151-163. 
90 A. Campos, I. Apraiz, R. R. da Fonseca and S. Cristobal, Proteomics, 2015, 15, 4021-4029.

91 R. Alves, O. Cordeiro, T. Silva, N. Richard, M. de Vareilles, G. Marino, P. Di Marco, P. Rodrigues and L. Conceicao, Aquaculture, 2010, 299, 57-66.

92 F. Provan, A. Bjornstad, D. M. Pampanin, E. Lyng, R. Fontanillas, O. K. Andersen, W. Koppe and S. Bamber, Mar. Environ. Res., 2006, 62(suppl), S105-S108.

93 O. D. Cordeiro, T. S. Silva, R. N. Alves, B. Costas, T. Wulff, N. Richard, M. de Vareilles, L. E. C. Conceição and P. M. Rodrigues, Mar. Biotechnol., 2012, 14, 714-729.

94 M. Morzel, C. Chambon, F. Lefevre, G. Paboeuf and E. Laville, J. Agric. Food Chem., 2006, 54, 2997-3001.

95 T. S. Silva, O. D. Cordeiro, E. D. Matos, T. Wulff, J. P. Dias, F. Jessen and P. M. Rodrigues, J. Agric. Food Chem., 2012, 60, 9443-9453.

96 H. Jiang, Y. Xie, B. Huang, J. Zhang, C. Zhang, S. Li, J. Xiang, F. Li, H. Jiang, F. Li, Y. Xie, B. Huang, J. Zhang, C. Zhang, S. Li and J. Xiang, Proteomics, 2009, 9, 3353-3367.

97 L. Sun, S. Liu, L. Bao, Y. Li, J. Feng and Z. Liu, Comp. Biochem. Physiol., Part D: Genomics Proteomics, 2015, 13, 60-69.

98 T. Wulff, E. K. Hoffmann, P. Roepstorff and F. Jessen, Proteomics, 2008, 8, 2035-2044.

99 R. W. Smith, P. Cash, S. Ellefsen and G. E. Nilsson, Proteomics, 2009, 9, 2217-2229.

100 B. A. Mendelsohn, J. P. Malone, R. R. Townsend and J. D. Gitlin, Comp. Biochem. Physiol., Part D: Genomics Proteomics, 2009, 4, 21-31.

101 E. Salas-Leiton, B. Canovas-Conesa, R. Zerolo, J. LopezBarea, J. P. Canavate and J. Alhama, Mar. Biotechnol., 2009, 11, 473-487.

102 W. W. Dowd, B. N. Harris, J. J. Cech Jr. and D. Kultz, J. Exp. Biol., 2010, 213, 210-224.

103 D. Kultz, D. Fiol, N. Valkova, S. Gomez-Jimenez, S. Y. Chan and J. Lee, J. Exp. Biol., 2007, 210, 1593-1601.

104 X. J. Lu, J. Chen, Z. A. Huang, Y. H. Shi and F. Wang, Comp. Biochem. Physiol., Part D: Genomics Proteomics, 2010, 5, 185-189.

105 S. Papakostas, A. Vasemägi, M. Himberg and C. R. Primmer, J. Proteomics, 2014, 105, 144-150.

106 A. Ibarz, M. Martin-Perez, J. Blasco, D. Bellido, E. de Oliveira and J. Fernandez-Borras, Proteomics, 2010, 10, 963-975.

107 L. McLean, I. S. Young, M. K. Doherty, D. H. Robertson, A. R. Cossins, A. Y. Gracey, R. J. Beynon and P. D. Whitfield, Proteomics, 2007, 7, 2667-2681.

108 M. F. Addis, R. Cappuccinelli, V. Tedde, D. Pagnozzi, M. C. Porcu, E. Bonaglini, T. Roggio and S. Uzzau, Aquaculture, 2010, 309, 245-252.

109 A. Bohne-Kjersem, A. Skadsheim, A. Goksoyr and B. E. Grosvik, Mar. Environ. Res., 2009, 68, 268-277.

110 J. Brunt, R. Hansen, D. J. Jamieson and B. Austin, Vet. Immunol. Immunopathol., 2008, 121, 199-205.

111 P. A. Fields, C. Eurich, W. L. Gao and B. Cela, J. Exp. Biol., 2014, 217, 1601-1612.

112 J. Letendre, M. Dupont-Rouzeyrol, A.-C. Hanquet, F. Durand, H. Budzinski, P. Chan, D. Vaudry and B. Rocher, Comp.
Biochem. Physiol., Part D: Genomics Proteomics, 2011, 6, 357-369.

113 R. Company, O. Antúnez, M. J. Bebianno, M. P. Cajaraville and A. Torreblanca, J. Proteomics, 2011, 74, 2909-2919.

114 P. A. Fields, K. M. Cox and K. R. Karch, Integr. Comp. Biol., 2012, 52, 636-647.

115 L. Tomanek, M. J. Zuzow, L. Hitt, L. Serafini and J. J. Valenzuela, J. Exp. Biol., 2012, 215, 3905-3916.

116 C. Cole, A. V. Coelho, R. H. James, D. Connelly and D. Sheehan, Mar. Environ. Res., 2014, 96, 29-37.

117 R. Company, A. Torreblanca, M. Cajaraville, M. J. Bebianno and D. Sheehan, Sci. Total Environ., 2012, 437, 413-421.

118 R. Breton and A. Boxall, QSAR Comb. Sci., 2003, 22, 399-409.

119 F. Silvestre, T. T. Huynh, A. Bernard, J. Dorts, M. Dieu, M. Raes, T. P. Nguyen and P. Kestemont, Comp. Biochem. Physiol., Part D: Genomics Proteomics, 2010, 5, 227-233.

120 M. Hampel, E. Alonso, I. Aparicio, J. L. Santos and M. Leaver, Mol. Cell. Proteomics, 2015, 14, 371-381.

121 M. De Wit, K. van der Ven, S. Vandamme, E. Witters, W. De Coen and D. Keil, Gen. Comp. Endocrinol., 2010, 167, 190-201.

122 Q. Xu, C. Y. Feng, T. S. Hori, D. A. Plouffe, J. T. Buchanan and M. L. Rise, Comp. Biochem. Physiol., Part D: Genomics Proteomics, 2013, 8, 317-333.

123 J. Y. Zhu, H. Q. Huang, X. D. Bao, Q. M. Lin and Z. Cai, Aquat. Toxicol., 2006, 78, 127-135.

124 G. Isani, G. Andreani, E. Carpenè, S. di Molfetta, D. Eletto and E. Spisni, Fish Shellfish Immunol., 2011, 31, 1051-1058.

125 I. Varo, G. Rigos, J. C. Navarro, J. del Ramo, J. CalduchGiner, A. Hernandez, J. Pertusa and A. Torreblanca, Chemosphere, 2010, 80, 570-577.

126 K. Mezhoud, A. L. Bauchet, S. Chateau-Joubert, D. Praseuth, A. Marie, J. C. Francois, J. J. Fontaine, J. P. Jaeg, J. P. Cravedi, S. Puiseux-Dao and M. Edery, Toxicon, 2008, 51, 1431-1439.

127 J. K. Nzoughet, J. T. Hamilton, C. H. Botting, A. Douglas, L. Devine, J. Nelson and C. T. Elliott, Mol. Cell. Proteomics, 2009, 8, 1811-1822.

128 O. Karlsen, K. Berg, M. Brattås, A. Bohne-Kjersem, B. Grøsvik, A. Goksøyr and S. Bjørneklett, J. Toxicol. Environ. Health, Part A, 2011, 74, 494-507.

129 Y. Jin, X. Zhang, D. Lu and Z. Fu, Arch. Environ. Contam. Toxicol., 2012, 62, 127-134.

130 J. Mi, I. Apraiz and S. Cristobal, Biomarkers, 2007, 12, 47-60. 131 J. Mi, A. Orbea, N. Syme, M. Ahmed, M. P. Cajaraville and S. Cristóbal, Proteomics, 2005, 5, 3954-3965.

132 I. Apraiz, M. P. Cajaraville and S. Cristobal, Mar. Pollut. Bull., 2009, 58, 1815-1826.

133 S. Cristobal, Methods Mol. Biol., 2008, 410, 123-135.

134 C. Riva, A. Binelli, F. Rusconi, G. Colombo, A. Pedriali, R. Zippel and A. Provini, Aquat. Toxicol., 2011, 104, 14-22.

135 J. Diehl, S. E. Johnson, K. Xia, A. West and L. Tomanek, Chemosphere, 2012, 87, 490-497.

136 F. Liu, D.-Z. Wang and W.-X. Wang, Environ. Toxicol. Chem., 2012, 31, 1292-1300.

137 A. Binelli, I. Marisa, M. Fedorova, R. Hoffmann and C. Riva, Aquat. Toxicol., 2013, 140-141, 268-278. 
138 C. Ji, H. Wu, L. Wei, J. Zhao, Q. Wang and H. Lu, Fish Shellfish Immunol., 2013, 35, 489-498.

139 C. Riva and A. Binelli, Comp. Biochem. Physiol., Part D: Genomics Proteomics, 2014, 9, 23-30.

140 T. Gomes, S. Chora, C. G. Pereira, C. Cardoso and M. J. Bebianno, Aquat. Toxicol., 2014, 155, 327-336.

141 A. Pedriali, C. Riva, M. Parolini, S. Cristoni, D. Sheehan and A. Binelli, Drug Test. Anal., 2013, 5, 646-656.

142 W. Schmidt, L.-C. Rainville, G. McEneff, D. Sheehan and B. Quinn, Drug Test. Anal., 2014, 6, 210-219.

143 A. Furey, S. O’Doherty, K. O'Callaghan, M. Lehane and K. J. James, Toxicon, 2010, 56, 173-190.

144 L. Huang, Y. Zou, H.-W. Weng, H.-Y. Li, J.-S. Liu and W.-D. Yang, Environ. Pollut., 2014, 196C, 350-357.

145 M. Malécot, B. Guével, C. Pineau, B. F. Holbech, M. Bormans and C. Wiegand, J. Proteome Res., 2013, 12, 5281-5292.

146 J. K. Nzoughet, I. R. Grant, P. A. Prodöhl, J. T. G. Hamilton, L. M. Botana and C. T. Elliott, Toxicon, 2011, 58, 619-622.

147 M. Puerto, A. Campos, A. Prieto, A. Cameán, A. M. de Almeida, A. V. Coelho and V. Vasconcelos, Aquat. Toxicol., 2011, 101, 109-116.

148 G. Ronzitti, A. Milandri, G. Scortichini, R. Poletti and G. P. Rossini, Toxicon, 2008, 52, 705-713.

149 S. Dios, B. Novoa, F. Buonocore, G. Scapigliati and A. Figueras, Rev. Fish. Sci., 2008, 16, 119-132.

150 X. P. Xiong, C. F. Dong, X. Xu, S. P. Weng, Z. Y. Liu and J. G. He, Dev. Comp. Immunol., 2011, 35, 431-440.

151 C. H. Yeh, Y. S. Chen, M. S. Wu, C. W. Chen, C. H. Yuan, K. W. Pan, Y. N. Chang, N. N. Chuang and C. Y. Chang, Biochem. Biophys. Res. Commun., 2008, 372, 674-680.

152 B. Chen, A. Zhang, Z. Xu, R. Li, H. Chen and M. Jin, J. Proteome Res., 2011, 10, 5163-5174.

153 Y. Luo, S. Weng, Q. Wang, X. Shi, C. Dong, Q. Lu, X. Yu and J. He, Virus Res., 2009, 144, 171-179.

154 A. Bourchookarn, P. O. Havanapan, V. Thongboonkerd and C. Krittanai, Biochim. Biophys. Acta, 2008, 1784, 504-511.

155 P. Sangsuriya, J. Y. Huang, Y. F. Chu, K. Phiwsaiya, P. Leekitcharoenphon, W. Meemetta, S. Senapin, W. P. Huang, B. Withyachumnarnkul, T. W. Flegel and C. F. Lo, Mol. Cell. Proteomics, 2014, 13, 269-282.

156 M. F. Addis, R. Cappuccinelli, V. Tedde, D. Pagnozzi, I. Viale, M. Meloni, F. Salati, T. Roggio and S. Uzzau, Proteome Sci., 2010, 8, 1-8.

157 A. Abbass, S. M. Sharifuzzaman and B. Austin, J. Fish Dis., 2010, 33, 31-37.

158 P. A. Kumar, T. S. S. Jyothsna, T. N. R. Srinivas, C. Sasikala, C. V Ramana and J. F. Imhoff, Int. J. Syst. Evol. Microbiol., 2007, 57, 1261-1265.

159 X. D. Ni, N. Wang, Y. J. Liu and C. P. Lu, FEMS Immunol. Med. Microbiol., 2010, 58, 363-373.

160 K. Somboonwiwat, V. Chaikeeratisak, H. C. Wang, C. F. Lo and A. Tassanakajon, Proteome Sci., 2010, 8, 39-49.

161 F. Yan, Y. L. Zhang, R. P. Jiang, M. Q. Zhong, Z. Hu, H. Du, J. S. Lun, J. H. Chen and Y. Y. Li, Fish Shellfish Immunol., 2011, 30, 354-360.
162 G. D. Stentiford, M. R. Viant, D. G. Ward, P. J. Johnson, A. Martin, W. Wenbin, H. J. Cooper, B. P. Lyons and S. W. Feist, OMICS, 2005, 9, 281-299.

163 T. S. Silva, O. Cordeiro, N. Richard, L. E. C. Conceicao and P. M. Rodrigues, Comp. Biochem. Physiol., Part D: Genomics Proteomics, 2011, 6, 82-91.

164 F. Dumetz, E. Duchaud, S. Claverol, N. Orieux, S. Papillon, D. Lapaillerie and M. Le Henaff, Microbiology, 2008, 154, 1793-1801.

165 S. W. Nho, J. Hikima, I. S. Cha, S. B. Park, H. B. Jang, C. S. del Castillo, H. Kondo, I. Hirono, T. Aoki and T. S. Jung, J. Bacteriol., 2011, 193, 3356-3366.

166 H. Li, X. P. Xiong, B. Peng, C. X. Xu, M. Z. Ye, T. C. Yang, S. Y. Wang and X. X. Peng, J. Proteome Res., 2009, 8, 4342-4349.

167 H. Li, M. Z. Ye, B. Peng, H. K. Wu, C. X. Xu, X. P. Xiong, C. Wang, S. Y. Wang and X. X. Peng, J. Proteome Res., 2010, 9, 2573-2583.

168 H. B. Jang, Y. R. Kim, I. S. Cha, S. W. Noh, S. B. Park, M. Ohtani, J. Hikima, T. Aoki and T. S. Jung, J. Fish Dis., 2011, 34, 555-562.

169 H. Bjornsson, V. P. Marteinsson, O. H. Friojonsson, D. Linke and E. Benediktsdottir, J. Appl. Microbiol., 2011, 111, 17-25.

170 X. P. Xiong, C. Wang, M. Z. Ye, T. C. Yang, X. X. Peng and H. Li, Mar. Biotechnol., 2010, 12, 686-695.

171 X. P. Xiong, B. W. Zhang, M. J. Yang, M. Z. Ye, X. X. Peng and H. Li, Fish Shellfish Immunol., 2010, 29, 810-816.

172 A. D. Kulkarni, V. Kiron, J. H. W. M. Rombout, M. F. Brinchmann, J. M. O. Fernandes, N. S. Sudheer and B. I. S. Singh, Proteomics, 2014, 14, 1660-1673.

173 E. Cubero-Leon, C. Minier, J. M. Rotchell and E. M. Hill, Comp. Biochem. Physiol., Part D: Genomics Proteomics, 2012, 7, 212-219.

174 M. Simonian, S. V. Nair, J. A. Nell and D. A. Raftos, J. Proteomics, 2009, 73, 209-217.

175 M. Simonian, S. V. Nair, W. A. O'Connor and D. A. Raftos, J. Fish Dis., 2009, 32, 367-375.

176 X. Xue, S. M. Hixson, T. S. Hori, M. Booman, C. C. Parrish, D. M. Anderson and M. L. Rise, Comp. Biochem. Physiol., Part D: Genomics Proteomics, 2015, 14, 1-15.

177 S. Ghisaura, R. Anedda, D. Pagnozzi, G. Biosa, S. Spada, E. Bonaglini, R. Cappuccinelli, T. Roggio, S. Uzzau and M. Addis, Proteome Sci., 2014, 12, 44-61.

178 S. Panserat and S. J. Kaushik, Aquacult. Res., 2010, 41, 751-762. 179 N. H. Sissener, S. A. Martin, P. Cash, E. M. Hevroy, M. Sanden and G. I. Hemre, Mar. Biotechnol., 2010, 12, 273-281.

180 S. Keyvanshokooh and A. Tahmasebi-Kohyani, Aquaculture, 2012, 324-325, 79-84.

181 T. S. Silva, A. M. R. da Costa, L. E. C. Conceição, J. P. Dias, P. M. L. Rodrigues and N. Richard, PeerJ, 2014, 2, 527-545.

182 E. L. Thompson, W. O’Connor, L. Parker, P. Ross and D. A. Raftos, Mol. Ecol., 2015, 24, 1248-1262.

183 E. M. Hartmann, E. Durighello, O. Pible, B. Nogales, F. Beltrametti, R. Bosch, J. A. Christie-Oleza and J. Armengaud, Mar. Genomics, 2014, 17, 35-42.

184 T. Urich, A. Lanzén, R. Stokke, R. B. Pedersen, C. Bayer, I. H. Thorseth, C. Schleper, I. H. Steen and L. Ovreas, Environ. Microbiol., 2014, 16, 2699-2710. 